\title{
Treatment of ErbB2 breast cancer by mitochondrial targeting
}

\author{
Sophia Eldad ${ }^{1 \dagger}$, Rachel Hertz ${ }^{1 \dagger}$, Gilad Vainer ${ }^{2}$, Ann Saada $^{3}$ and Jacob Bar-Tana ${ }^{1 *}$
}

\begin{abstract}
Background: ErbB2 breast cancer still remains an unmet need due to primary and/or acquired resistance to current treatment strategies. MEDICA compounds consist of synthetic long-chain a, $\omega$-dicarboxylic acids previously reported to suppress breast cancer in PyMT transgenic mice.

Methods: MEDICA efficacy and mode of action in the ErbB2 context was studied in ErbB2 transgenic mice and human breast cancer cells.

Results: MEDICA treatment is shown here to suppress ErbB2 breast tumors and lung metastasis in ErbB2/neu MMTV transgenic mice, to suppress ErbB2/neu xenografts in nod/scid mice, and to suppress survival of AU565 and BT474 human ErbB2 breast cancer cells. Suppression of ErbB2 breast tumors by MEDICA is due to lipid raft disruption with loss of ErbB family members, including EGFR, ErbB2, and ErbB3. In addition, MEDICA inhibits mTORC1 activity, independently of abrogating the ErbB receptors and their signaling cascades. The double hit of MEDICA in abrogating ErbB and mTORC1 is partly accounted for by targeting mitochondria complex I.

Conclusions: Mitochondrial targeting by MEDICA suppresses ErbB2 breast tumors and metastasis due to lipid raft disruption and inhibition of mTORC1 activity. Inhibition of mTORC1 activity by MEDICA avoids the resistance acquired by canonical mTORC1 inhibitors like rapalogs or mTOR kinase inhibitors.
\end{abstract}

Keywords: Breast cancer, ErbB2, mTORC1, Lipid rafts, Mitochondria

\section{Background}

Breast cancer is the most common female cancer and the second leading cause of cancer-related death in women in developed countries [1]. ErbB2 (HER2) breast tumors comprise $20-25 \%$ of breast cancer cases, half of which are also hormone-receptor positive (Luminal B). Amplification of ErbB2 leads to constitutive ligand-independent ErbB2 homodimerization or heterodimerization with ErbB family members (ErbB1/EGFR, ErbB3), leading to recruitment and activation of the PI3K/Akt/mTORC1, MEK/ ERK/mTORC1, and c-Src/JAK/STAT3 transducers that control cell proliferation, survival, angiogenesis, and

\footnotetext{
* Correspondence: jacobb@ekmd.huji.ac.il

${ }^{+}$Sophia Eldad and Rachel Hertz contributed equally to this work.

'Dept of Human Nutrition and Metabolism, Hebrew University Medical School, 91120 Jerusalem, Israel

Full list of author information is available at the end of the article
}

metastasis. ErbB2 breast cancer is treated with chemotherapy, surgery, and ErbB2-targeting agents (e.g., trastuzumab, prastuzumab, lapatinib) [1-3]. However, 20\% of ErbB2 patients present primary resistance to ErbB2 targeting agents and $\sim 70 \%$ of patients with ErbB2 metastatic breast cancer who initially respond acquire resistance within 1 year [2]. Hence, in spite of the advances accomplished in treating ErbB2 breast cancer, the ErbB2 challenge still remains an unmet need.

Breast cancer is mostly diagnosed in postmenopausal women aged 50 and above, namely, a population heavily inflicted by type 2 diabetes (T2D) or prediabetes $(50 \%$ prevalence in females aged $\geq 50$ [4]). Indeed, T2D increases the relative risk of breast cancer morbidity and mortality by 1.2 - and 1.8 -fold [5], respectively. The increase in breast cancer due to T2D is ascribed to basal insulin resistance/hyperinsulinemia, with insulin acting

C C The Author(s). 2020 Open Access This article is licensed under a Creative Commons Attribution 4.0 International License, which permits use, sharing, adaptation, distribution and reproduction in any medium or format, as long as you give appropriate credit to the original author(s) and the source, provide a link to the Creative Commons licence, and indicate if changes were made. The images or other third party material in this article are included in the article's Creative Commons licence, unless indicated otherwise in a credit line to the material. If material is not included in the article's Creative Commons licence and your intended use is not permitted by statutory regulation or exceeds the permitted use, you will need to obtain permission directly from the copyright holder. To view a copy of this licence, visit http://creativecommons.org/licenses/by/4.0/. The Creative Commons Public Domain Dedication waiver (http://creativecommons.org/publicdomain/zero/1.0/) applies to the data made available in this article, unless otherwise stated in a credit line to the data. 
as mitogenic growth factor. In line with that, insulinresistant hyperinsulinemic animal models inoculated with mouse mammary carcinoma cells present advanced mammary tumors [6, 7]. Similarly, treatment of T2D patients with insulin or insulin secretagogues (e.g., sulfonylurea) is associated with significantly higher risk of breast cancer $[8,9]$, whereas retrospective clinical studies have indicated improved disease-free and overall survival of diabetic ErbB2 breast cancer patients treated with insulin sensitizers (metformin, thiazolidinediones) [10-13]. Increase in survival due to metformin and metformin-analogues has also been reported in transgenic ErbB2/neu mice [14-16], implying that add-on insulin sensitizers may improve survival of non-diabetic ErbB2 breast cancer.

MEDICA compounds consist of synthetic long-chain $\alpha, \omega$-dicarboxylic acids, substituted in the $\alpha \alpha^{\prime}$ or $\beta \beta^{\prime}$ carbons [HOOC-C $\left(\alpha^{\prime}\right)-\mathrm{C}\left(\beta^{\prime}\right)-\left(\mathrm{CH}_{2}\right)_{n}-\mathrm{C}(\beta)-\mathrm{C}(\alpha)-\mathrm{COOH}, n \geq$ 10] [17-21]. MEDICA analogues may be thio-esterified endogenously to their respective CoA-thioesters, but in contrast to natural long-chain fatty acids (LCFA), these compounds are not incorporated into lipids, while the substitutions at the $\alpha \alpha^{\prime}$ or $\beta \beta^{\prime}$ positions block their $\beta$ oxidation. MEDICA analogues are mostly excreted in bile as respective glucuronides. MEDICA compounds simulate LCFA in activating AMP-activated protein kinase (AMPK) (being 20-folds more potent than metformin) [17] and in suppressing adenylate cyclase [19]. MEDICA compounds proved potent anti-diabetic efficacy in type II and I diabetic animal models $[17,18,20]$, while suppressing diabetes-induced colorectal cancer [21]. Also, MEDICA treatment has previously been reported by us to suppress triple-negative breast tumor growth and lung metastasis of mice and cells expressing the polyoma middle $\mathrm{T}$ antigen (PyMT) driven by the mammary MMTV promoter (MMTV-PyMT) [22]. These considerations prompted our interest to study MEDICA activity in the ErbB2 breast cancer context. MEDICA treatment is shown here to suppress ErbB2 breast cancer in vivo and cell lines by targeting mitochondrial oxidative phosphorylation, resulting in suppression of ErbB family members and inhibition of mTORC1 activity.

\section{Methods}

\section{Animals and diets}

FVB-tg(MMTV-ErbB2) female mice (Jackson Laboratory) express activated rat ErbB2 (c-neu, V664G) oncogene under the direction of the mouse mammary tumor virus (MMTV) promoter [23]. Mice were kept in standard SPF conditions in 12-h light/dark periods, with free access to food and water. Four-month-old mice were fed for 8 weeks with either regular chow or MEDICA in feed $(0.04 \% \mathrm{~W} / \mathrm{W})$. Upon sacrifice, mice were anesthetized using ketamine/xylazine; breasts were photographed, dissected, and weighed; and breast tumors and lungs were immediately frozen in liquid nitrogen for RNA and protein analysis. Tumor volume was estimated by measurement of width and length of breast tumor foci and calculated by the formula $4 \pi / 3\left(((W+L) / 4)^{3}\right)$. Lung metastasis was determined by rat ErbB2 neu transcript by qRT-PCR.

Immortalized ErbB2/neu cells from FVB MMTV ErbB2 neu breast tumors (RH2111 cells) were subcutaneously xenografted to NOD/SCID (Jackson Laboratory) female mice $\left(5 \times 10^{6}\right.$ cells per mouse). Tumors were visible 1 week after injection. Mice with visible tumors were fed with either regular chow or MEDICA in feed $(0.04 \% \mathrm{~W} / \mathrm{W})$, followed by caliper monitoring tumor volumes for 30 days. Mice were anesthetized using ketamine/xylazine, and tumors were sampled and weighed.

\section{Cultured cells}

Human AU565 (ATCC CRL-2351) and BT474 (ATCC HTB-20) cells were cultured in RPMI-1640 (Biological Industries, Beit Haemek, Israel) supplemented with 10\% fetal calf serum, $2 \mathrm{mM}$ L-glutamine, and penicillin/ streptomycin solution at $37^{\circ} \mathrm{C}$ in humidified atmosphere containing 5\% $\mathrm{CO} 2$ in the presence of additions as indicated. Human MCF10 cells were cultured in DMEM/ F12 (Biological Industries, Beit Haemek, Israel) supplemented with $5 \%$ horse serum, $20 \mathrm{ng} / \mathrm{ml} \mathrm{EGF,} 0.5 \mu \mathrm{g} / \mathrm{ml}$ hydrocortisone, $100 \mathrm{ng} / \mathrm{ml}$ cholera toxin, $10 \mu \mathrm{g} / \mathrm{ml}$ insulin, and penicillin/streptomycin solution at $37{ }^{\circ} \mathrm{C}$ in humidified atmosphere containing 5\% CO2. RH2111 cells were derived from FVB MMTV ErbB2 neu breast tumors. Excised tumors were disintegrated in serum-free mammary epithelial cell growth medium $\left(\mathrm{MEGM}^{\mathrm{TM}}\right)$ (Lonza). Fibroblasts were removed by 3-4 rounds of trypsinization, yielding cells that displayed exclusive epithelial morphology over subsequent passages. RH2111 cells were cultured in DMEM/F12 medium supplemented with $10 \%$ fetal calf serum in the presence of additions as indicated. Trastuzumab-resistant AU565 and BT474 cells were derived by continuously culturing parental cells for 4 months with increasing concentrations of trastuzumab (Roche) up to $5 \mu \mathrm{g} / \mathrm{ml}$. Resistant cells were maintained in $4 \mu \mathrm{g} / \mathrm{ml}$ trastuzumab. Cells were routinely tested for Mycoplasma by the EZ-PCR kit (Biological Industries, Beit Haemek, Israel). Cell growth was quantified using the methylene blue assay. Where indicated, cells were cultured in medium containing $10 \mathrm{mM}$ galactose instead of glucose. Where indicated, EGF (50 $\mathrm{ng} / \mathrm{ml}$ ) was added during the last $15 \mathrm{~min}$ of incubation.

\section{Anchorage-dependent colony assay}

Cells seeded on $60-\mathrm{mm}$ plates (5000cells/well) were allowed to form colonies for 18 days in the presence of 
added MEDICA as indicated. Colonies were fixated with $0.625 \%$ glutaraldehyde and stained with methylene blue. Colonies that reached $\geq 400 \mathrm{um}$ in size were counted.

\section{Soft agar colony assay}

Cells were seeded on $0.5 \%$ bottom agar $60-\mathrm{mm}$ plates with culture medium containing $0.3 \%$ agar and 5000 cells. Cells were incubated with $0,150 \mu \mathrm{M}$, and $200 \mu \mathrm{M}$ MEDICA for 25 days. Colonies that reached $\geq 100 \mathrm{um}$ in size were counted.

\section{Tumor spheroids}

BT474 spheroids were generated in polyHEMA-coated U-shaped 96-well plates. Fifty microliters of $0.5 \%$ polyHEMA (Sigma) in 95\% ethanol was added to each well and allowed to evaporate in $37{ }^{\circ} \mathrm{C} .4-5 \times 10^{3}$ BT474 cells, or BT474 cells infected with empty or NDI1 virus as indicated, were added to each well in $50 \mu \mathrm{l}$ RPMI1640 medium supplemented with $10 \%$ fetal calf serum, $2 \mathrm{mM}$ L-glutamine, penicillin/streptomycin solution, and $2 \%$ matrigel, and the plate centrifuged at $250 \mathrm{~g}$ for $5 \mathrm{~min}$. Spheroids were allowed to form and were treated as indicated. Spheroid viability was assayed by acid phosphatase [23].

\section{Lenti- and retrovirus infections}

Human AMPK $\alpha 1 / A M P K \alpha 2$ ShRNA was from Jones RG (Goodman Cancer Research center, McGill University Montreal Canada). ShREDD1 (NM-019058) was from Sigma Mission. ShSestrin2 was from Budanov AV (Department of human and molecular genetics Virginia Commonwealth University VA, USA). NDI1 plasmid was from Addgene. Cells infected with control virus or shAMPK, shSestrin2, or shREDD1 plasmids were selected by puromycin. Cells infected with empty or NDI1 were selected by blasticidine.

\section{Cell cycle distribution}

Cells were trypsinized, washed with cold PBS, suspended in $\mathrm{PBS} / 70 \%$ ethanol, and kept at $-20^{\circ} \mathrm{C}$. For FACS analysis, cells were centrifuged, washed with PBS, and suspended in $700 \mu \mathrm{l}$ propidium iodide (PI)/Triton X-100/ RNAase A staining solution $(20 \mu \mathrm{g} / \mathrm{ml}$ PI, $0.1 \%$ Triton $\mathrm{X}-100,0.1 \mathrm{mg} / \mathrm{ml}$ RNAase A in PBS). Cell cycle distribution was analyzed using FACScan (BD Biosciences).

\section{Immunofluorescence}

Cells were grown on cover slips and treated as indicated. Following treatment, cells were rinsed with PBS and fixed with $4 \%$ paraformaldehyde for $30 \mathrm{~min}$, permeabilized with $0.1 \%$ Triton X-100 in $1 \%$ FBS for 5 min, and blocked with $0.1 \%$ FBS for $30 \mathrm{~min}$. Fixated cells were incubated overnight with primary antibodies for EGFR (1:50), ErbB2 (1:100), or caveolin $1(1: 100)$ at $4{ }^{\circ} \mathrm{C}$, followed by incubation with the secondary antibody $\mathrm{Cy}$ 3 conjugated donkey anti rabbit IgG (1:300) (Jackson Immunoresearch). Slides were mounted with DAPI 2ug/ $\mathrm{ml}$ for nuclei visualization. Fluorescent intensity was analyzed by confocal microscopy (Zeiss LSM 710; Axioobserver Z1).

\section{Biotin tagging of plasma membrane proteins}

Cells were treated as indicated and rinsed on ice three times with PBSCM (PBSx $1 \mathrm{pH}$ 8.0, $0.5 \mathrm{mM} \mathrm{CaCl}, 1 \mathrm{mM}$ $\mathrm{MgCl}_{2}$ ), followed by adding non-permeable Sulfo-NHSSS-Biotin (Thermo Scientific) in PBSCM $(0.5 \mathrm{mg} / \mathrm{ml})$ for $15 \mathrm{~min}$. Cells were then rinsed with PBSCM, quenched for 10 min at $4{ }^{\circ} \mathrm{C}$ with glycine buffer (PBSx1 pH 8.0, 0.1 $\mathrm{M}$ Tris $\mathrm{pH}$ 8.0, $192 \mathrm{mM}$ glycine), and rinsed twice with PBSx1 pH 8.0, followed by lysing the cells in lysis buffer [24]. Cells were then centrifuged at $12,000 \mathrm{~g}$ for $15 \mathrm{~min}$ at $4{ }^{\circ} \mathrm{C}$, supernatant aliquot was kept at $-70{ }^{\circ} \mathrm{C}$ for further Western analysis, and the rest incubated overnight at $4{ }^{\circ} \mathrm{C}$ with $25 \mu \mathrm{l}$ of streptavidin beads (Streptavidin Agarose Resin, Thermo Scientific). Beads were rinsed three times with lysis buffer and subjected to Western analysis [24].

\section{Ganglioside (GM1) staining}

Cells seeded on cover slip were rinsed on ice with RPMI1640, stained on ice for $1 \mathrm{~h}$ in the dark with cholera toxin subunit B labeled with Alexa Fluor $555(5 \mu \mathrm{g} /$ $\mathrm{ml}$ RPMI1640), rinsed 3 times with PBS, and fixed with $4 \%$ PFA for $10 \mathrm{~min}$ on ice, followed by $10 \mathrm{~min}$ at room temperature. Slides were mounted with DAPI $2 \mu \mathrm{g} / \mathrm{ml}$ for nuclei visualization. Fluorescence intensity was analyzed by confocal microscopy (Zeiss LSM 710; Axioobserver Z1).

\section{Caveolin staining}

Cells were trypsinized, centrifuged for $5 \mathrm{~min}$ at $1000 \mathrm{~g}$, rinsed in $\mathrm{PBS} / 1 \mathrm{mM} \mathrm{MgCl} 2$ (PBSM), and centrifuged and fixated with $4 \%$ paraformaldehyde for $10 \mathrm{~min}$ at 4 ${ }^{\circ} \mathrm{C}$, followed by $15 \mathrm{~min}$ at room temperature. Fixated cells were rinsed with PBSM, suspended in PBSM/3\% FCS for $15 \mathrm{~min}$, and incubated with anti-caveolin 1 antibody for $30 \mathrm{~min}$ at room temperature. Cells were then rinsed in $\mathrm{PBSM} / 3 \% \mathrm{FCS}$, suspended for $30 \mathrm{~min}$ in $\mathrm{PBSM} / 3 \%$ FCS containing secondary antibody $\mathrm{Cy}-3$ conjugated donkey anti rabbit IgG (1:200) (Jackson Immunoresearch), rinsed in PBSM $/ 3$ \% FCS, and re-suspended in PBSM/3\% FCS. Caveolin was analyzed using FACScan (BD Biosciences).

\section{GM1-rich membrane fractions}

Cells were washed with ice-cold PBS, scraped with 500 $\mathrm{mM}$ sodium carbonate $\mathrm{pH} 11$, homogenized using a loose fitting Dounce homogenizer (10 strokes), and then 
sonicated (three 10-s bursts; SONICS vibra cell ultrasonic processor). The homogenate was adjusted to $45 \%$ sucrose by adding $90 \%$ sucrose prepared in MBS ( 25 $\mathrm{mM}$ Mes, $\mathrm{pH} 6.5,0.15 \mathrm{M} \mathrm{NaCl}$ ), was placed at the bottom of an ultracentrifuge tube, followed by layering a $35-5 \%$ discontinuous sucrose gradient prepared in MBS containing $250 \mathrm{mM}$ sodium carbonate, and centrifuged at 32,000 rpms for $21 \mathrm{~h}$ in an SW41 rotor (Optima L-90 $\mathrm{K}$ Ultracentrifuge Bekman Coulter). Gradient fractions were dot blotted on nitrocellulose and analyzed for GM1 using HRP-conjugated cholera toxin followed by ECL. For ErbB2, gradient fractions were subjected to Western blot analysis using anti-ErbB2 antibody.

\section{Oxygen consumption}

Cells were seeded on XF 24-well microplates (Seahorse Bioscience) at $40 \times 10^{3}$ cells/well in culture medium. Following $16 \mathrm{~h}$, medium was replaced with Leibovitz L15 medium containing $2 \mathrm{mM}$ glutamine and $10 \%$ fetal calf serum (FCS). One hour prior to assay, the medium was replaced by Leibovitz L15 containing $2 \mathrm{mM}$ glutamine without FCS. Measurement of basal respiration in the presence of added vehicle or MEDICA was followed by sequential additions of oligomycin $(2 \mu \mathrm{M})$, FCCP (1 $\mu \mathrm{M})$, and antimycin $\mathrm{A}(4 \mu \mathrm{M})$.

\section{Isolation of mitochondria}

Mouse brain mitochondria were isolated by differential centrifugation. Tissue was homogenized in buffer A (320 mM sucrose, 5 mM Tris-HCl, 2 mM EGTA, pH 7.4) using a Dounce homogenizer (Teflon glass) and centrifuged for $3 \mathrm{~min}$ at $2000 \mathrm{~g}$ to remove nuclei and cell debris. The supernatant was centrifuged for $10 \mathrm{~min}$ at 12 , $000 \mathrm{~g}$ at $4{ }^{\circ} \mathrm{C}$, and the pellet was re-suspended in buffer A containing $0.02 \%$ digitonin (Sigma-Aldrich) and recentrifuged. The mitochondrial pellet was washed again twice with buffer A and kept at $-80^{\circ} \mathrm{C}$ until use.

\section{Activity of mitochondrial electron transport components} Enzymatic activities of respiratory chain complexes were measured at $37{ }^{\circ} \mathrm{C}$ by standard spectrophotometry [25]. Briefly, complex I was measured by rotenone-sensitive $\mathrm{NADH}-\mathrm{CoQ} 1$ reduction. Complex II was measured by succinate-CoQ1 reduction. Complexes I + III were measured by NADH-cytC reduction. Complexes II + III were measured by succinate-cytC reduction. Complex IV was measured by the oxidation of reduced cytC. NADH dehydrogenase activity was measured by NADHferricyanide reduction. Succinic dehydrogenase (SDH) activity was measured by succinate-mediated reduction of phenazine methosulphate coupled to dichlorophenolindophenol. Citrate synthase (CS), a ubiquitous mitochondrial matrix enzyme serving as normalizer, was measured in the presence of acetyl-CoA and oxaloacetate by the release of CoASH coupled to $5^{\prime}, 5^{\prime}$ dithiobis (2-nitrobenzoic acid). Activities of mitochondrial respiratory chain complexes in the presence of added MEDICA are presented relative to respective activities in the presence of vehicle (DMSO).

\section{Mitochondrial superoxide production}

Cells were treated with 200uM MEDICA for $5 \mathrm{~h}$ followed by adding $3.3 \mu \mathrm{g} / \mathrm{ml}$ MitoSOX (Molecular Probes) for the last $30 \mathrm{~min}$. Cells were trypsinized and analyzed using FACScan (BD Biosciences).

\section{Cellular ATP}

Cells were seeded in 96-well plates at $10 \times 10^{3}$ cells/well and treated as indicated. Cells were then rinsed twice with RPMI followed by $50 \mu \mathrm{l}$ of RPMI and $25 \mu \mathrm{l}$ of lysis solution for $5 \mathrm{~min}$. Fifty-microliter aliquot was subjected to ATP measurement by the ATPlite luminescence kit (PerkinElmer).

\section{qRT-PCR}

RNA was purified from frozen mouse tissues using the Total RNA Mini Kit (Geneaid). $0.5 \mathrm{mg}$ sample was used as template for cDNA synthesis using M-MLV reverse transcriptase (Invitrogen). Real-time PCR was carried out (Rotorgene, Corbett Research) using KAPA SYBR FAST qPCR MIX (Kapa Biosystems) with the following primers (5' to 3'): rat ErbB2 (neu) (Fw:AGGAGGACGA GTCCTTGTAGT, Rev: GCTCAGAGACCTGCTT TGGA); mouse B-act:(Fw: GGCTGTATTCCCCTCCAT CG, Rev: CCAGTTGGTAACAATGCCATGT). mRNA was quantified using the $\Delta \Delta C$ t method.

\section{Cell lysis and Western blotting}

Cultured cells were scraped with lysis buffer $(50 \mathrm{mM}$ Tris $\mathrm{HCl} \mathrm{pH} 8.0,1 \%$ Triton X-100, $1 \mathrm{mM}$ EGTA, 1 $\mathrm{mmol} / \mathrm{L}$ EDTA, $150 \mathrm{mM} \mathrm{NaCl}, 5 \mathrm{mM} \mathrm{NaPPi}, 50 \mathrm{mM}$ $\mathrm{NaF}, 1 \mathrm{mM}$ PMSF, $1 \mathrm{mM}$ Na Vanadate, $40 \mathrm{nM}$ bpVfan and protease inhibitor cocktail (Sigma)). Frozen tumor samples were sonicated (three 10-s bursts) in lysis buffer (50 mM Tris $\mathrm{HCl} \mathrm{pH} \mathrm{7.4,1 \%} \mathrm{NP40,} 150 \mathrm{mM} \mathrm{NaCl}, 10$ $\mathrm{mM} \mathrm{NaF}, 1 \mathrm{mM}$ Na Vanadate, 100uM PMSF, $10 \mathrm{mM} \beta$ glycerophosphate, $40 \mathrm{nM}$ bpVfan, and protease inhibitor cocktail). Cell lysates were then centrifuged for $15 \mathrm{~min}$ at $12,500 \mathrm{rpm}$, and tumor samples were centrifuged for $5 \mathrm{~min}$ at $14,000 \mathrm{rpm}$. Protein concentration was determined by BCA (Thermo Scientific). Western blots were analyzed as previously described [24].

\section{Antibodies and reagents}

Anti-neu/HER2 (ErbB2) antibody was from Invitrogen. Anti-ErbB2, anti-ErbB3, anti-EGFR, anti-caveolin-1, anti-phospho-ERK(Tyr204), anti-ERK, anti-phosphoStat3(Tyr705), and anti-NDRG1 antibodies were from 
Santa Cruz Biotechnology INC. Anti-phosphoEGFR(Tyr1068) and anti-phospho-ErbB2(Tyr1248) antibodies were from Abcam. Anti- $\alpha$-tubulin, anti- $\beta$-actin, and anti-cholera toxin $B$ subunit antibodies were from Sigma Aldrich. Anti-4EBP1, anti-AMPK $\alpha$, anti-acetylCoA carboxylase, anti-S6 ribosomal protein, anti-p70 S6 kinase, anti-Akt, anti-phospho-4EBP1(Thr37/46), antiphospho-Akt(Thr308), anti-phospho-Akt(Ser473), antiphospho-acetyl-CoA carboxylase(Ser79), anti-phosphoAMPKo(Thr172), anti-phospho-p70 S6 kinase(Thr 389), and anti-phospho-S6 Ribosomal protein(Ser240/244) antibodies were from Cell Signaling. Anti-Sestrin2 and anti-REDD1 antibodies were from Proteintech. Cholera toxin subunit B (CT-B) Conjugates were from Molecular Probes. $\mathrm{Cy}^{\mathrm{TM}} 3$ Conjugate was from Jackson ImmunoResarch Lab. EGF was from Perprotech. MEDICA $\left[\alpha, \alpha^{\prime}-\right.$ tetramethyl hexadecanedioic acid, HOOC-C(CH3)2-
(CH2)12- $\mathrm{C}(\mathrm{CH} 3) 2-\mathrm{COOH}]$ was synthesized as previously described $[17,26]$.

\section{Statistics}

Statistics was performed by two-tailed repeated measure analysis of variance (GraphPad). Significance $(P<0.05)$ was analyzed by unpaired $t$-test with Welch correction.

\section{Results}

Suppression of ErbB2 breast cancer by the MEDICA analogue $\left.\mathrm{HOOC}-\mathrm{C}\left(\mathrm{CH}_{3}\right)_{2}-\mathrm{CH}_{2}\right)_{12}-\mathrm{C}\left(\mathrm{CH}_{3}\right)_{2}-\mathrm{COOH}$ in vivo has been verified in 4-month FVB MMTV-ErbB2/neu transgenic mice [27] treated with MEDICA in feed for 8 weeks (Fig. 1). MEDICA treatment resulted in decrease in tumor number, weight, and volume (Fig. 1a); loss of ErbB1, ErbB2, and ErbB3 in breast tumors (Fig. 1b); and decrease in lung metastatic neu cells (Fig. 1c). Since breast cancer

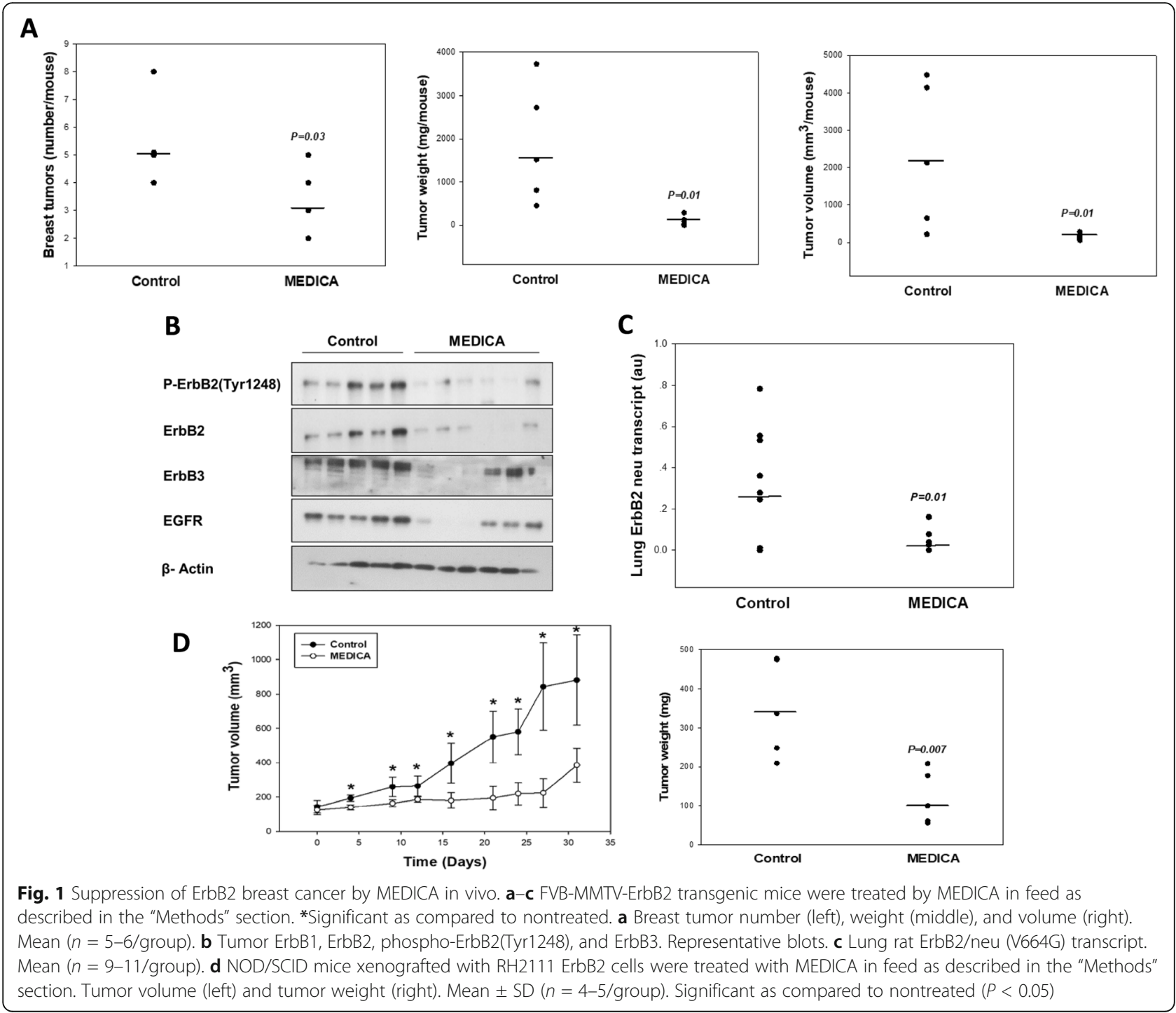


neu cells accumulate in lung blood vessels but do not produce solid lung metastases [28], metastasis was evaluated by the amount of the neu transcript in lung tissue, using rat neu-specific PCR. Suppression of ErbB2 breast cancer by MEDICA in vivo was further verified in nude mice xenografted with immortalized RH2111 ErbB2/neu cells derived from breast tumors of the FVB MMTV-ErbB2/neu transgene. MEDICA treatment resulted in decrease in RH2111 tumor volume and weight (Fig. 1d).

Suppression of ErbB2 cell growth and survival by MEDICA was further verified in mouse RH2111 ErbB2/ neu cells and human breast cancer cell lines AU565 and BT474 that overexpress ErbB2. BT474 is a Luminal B cell that further expresses progesterone receptors [29]. MEDICA treatment resulted in suppressing growth of RH2111, AU565, and BT474 cells, but not the nontumorigenic MCF10 epithelial cells (Fig. 2a). Growth suppression was further verified by formation of anchorage-dependent colonies, anchorage-independent colonies, and spheroid survival reported to be resistant to a variety of chemotherapy drugs [30] (Fig. 2b-d). Most importantly, cell growth of trastuzumab-resistant ErbB2 cells was similarly suppressed by MEDICA (Fig. 2e). Suppression of proliferation was accounted for by G1 cell cycle arrest, being accompanied by sub-G1 apoptotic cells (Fig. 2f). The $\mu \mathrm{M}$ concentrations of MEDICA reflect the high binding affinity of MEDICA to serum albumin [higher than 99\%, independently of MEDICA concentrations in the range of 0-0.9 mM (Advinus N079 study)], resulting in nM concentrations of the free MEDI $\mathrm{CA}$ acid in the culture medium.

In line with MEDICA effect in suppressing ErbB family members in transgenic ErbB2 breast cancer mice in vivo (Fig. 1b), loss of ErbB members and suppression of their respective transduction pathways were further verified in AU565 and BT474 human breast cancer cells. Plasma membrane ErbB members were determined by immunofluorescence (Fig. 3a) and biotin tagging (Fig. $3 \mathrm{~b})$ and found to be robustly decreased by MEDICA, together with decrease in respective total ErbB content (Fig. 3b). Since a variety of receptor tyrosine kinases (RTK), including ErbB members, are located in plasma membrane lipid rafts that enable close proximity of their respective transducing components [31, 32], the loss of plasma membrane ErbB members was further studied in terms of putative lipid raft disruption by MEDICA, as verified by caveolin-1 and GM1 ganglioside immunofluorescence. MEDICA treatment resulted in decreasing plasma membrane caveolin-1 and in decreasing, punctuating, and clustering surface GM1 (Fig. 3c, d) [33]. Lipid raft disruption by MEDICA was further verified by density gradient centrifugation. MEDICA treatment resulted in decreasing GM1 buoyancy, with concomitant loss of lipid raft ErbB2 (Fig. 3e). Hence, MEDICA effects in suppressing ErbB2 cell survival may be ascribed to loss of ErbB family members.

Loss of ErbB members by MEDICA was accompanied by suppression of their downstream phosphoAkt(Ser473), in the basal state and upon being induced by added EGF (Fig. 4a). Inhibition of Akt by MEDICA was further accompanied by suppressing mTORC1, as verified by mTORC1 downstream substrates phosphoS6K1(Thr389), phospho-S6(Ser240/244), phospho4EBP(Thr37/46), and total 4EBP pattern (Fig. 4b). Surprisingly however, suppression of mTORC1 activity by MEDICA could not be accounted for by loss of its ErbB drivers. Thus, inhibition of mTORC1 activity by MEDI CA precedes by hours MEDICA effects in causing ErbB loss (Fig. 4c), implying that inhibition of mTORC1 activity by MEDICA is not due to loss of ErbB family members. Also, inhibition of mTORC1 activity by rapamycin (Fig. 4d) or mTOR kinase inhibitor (e.g., Torin) (Fig. 4e) does not result in loss of ErbB family members, implying that the two concerned activities of MEDICA, namely, ErbB loss and suppression of mTORC1 activity, are independently driven by an upstream cofounder.

Lipid raft clustering and mTORC1 activity may both be modulated by metabolic stress [34, 35]. Indeed, similarly to MEDICA, P-ErbB2(Tyr1248), P-Akt, and mTORC1 activity were suppressed by inhibition of mitochondrial complex I by rotenone (Fig. 4f), prompting our interest in studying MEDICA activity in driving mitochondrial stress and its role in ErbB loss and inhibition of mTORC1 activity. MEDICA treatment of AU565 cells resulted in inhibiting mitochondrial basal and FCCP-uncoupled oxygen consumption (Fig. 5a). Suppression of mitochondrial respiration by MEDICA was accounted for by inhibition of mitochondrial complexes I and III (Fig. 5b), accompanied by decrease in cellular ATP content (Fig. 5c) and increased mitochondrial superoxide production (Fig. 5d). MEDICA-induced mitochondrial superoxide could be partly rescued by added methylene blue that bypasses mitochondrial complexes I-III [36] (Fig. 5d) or upon by-passing mitochondrial complex I by infected yeast NADH ubiquinone reductase (NDI1) [37] (Fig. 5e). Rescue by NDI1 was further verified and better exemplified in cells cultured in galactose instead of glucose, namely growth conditions that drive metabolic dependence on mitochondrial oxidative phosphorylation [38]. Most importantly, infection with NDI1 resulted in partly rescuing MEDICA suppression of ErbB1, ErbB2, and ErbB3, and their downstream target phospho-Akt(Thr308, Ser473), as well as in rescuing MEDICA inhibition of mTORC1 downstream substrates phospho-S6K1(Thr389), phospho-S6(Ser240/ 244), and phospho-4EBP(Thr37/46) (Fig. 6a-c). Concomitantly, infected NDI1 resulted in partial rescue of cell growth (Fig. 6d) and spheroid viability (Fig. 6e). 


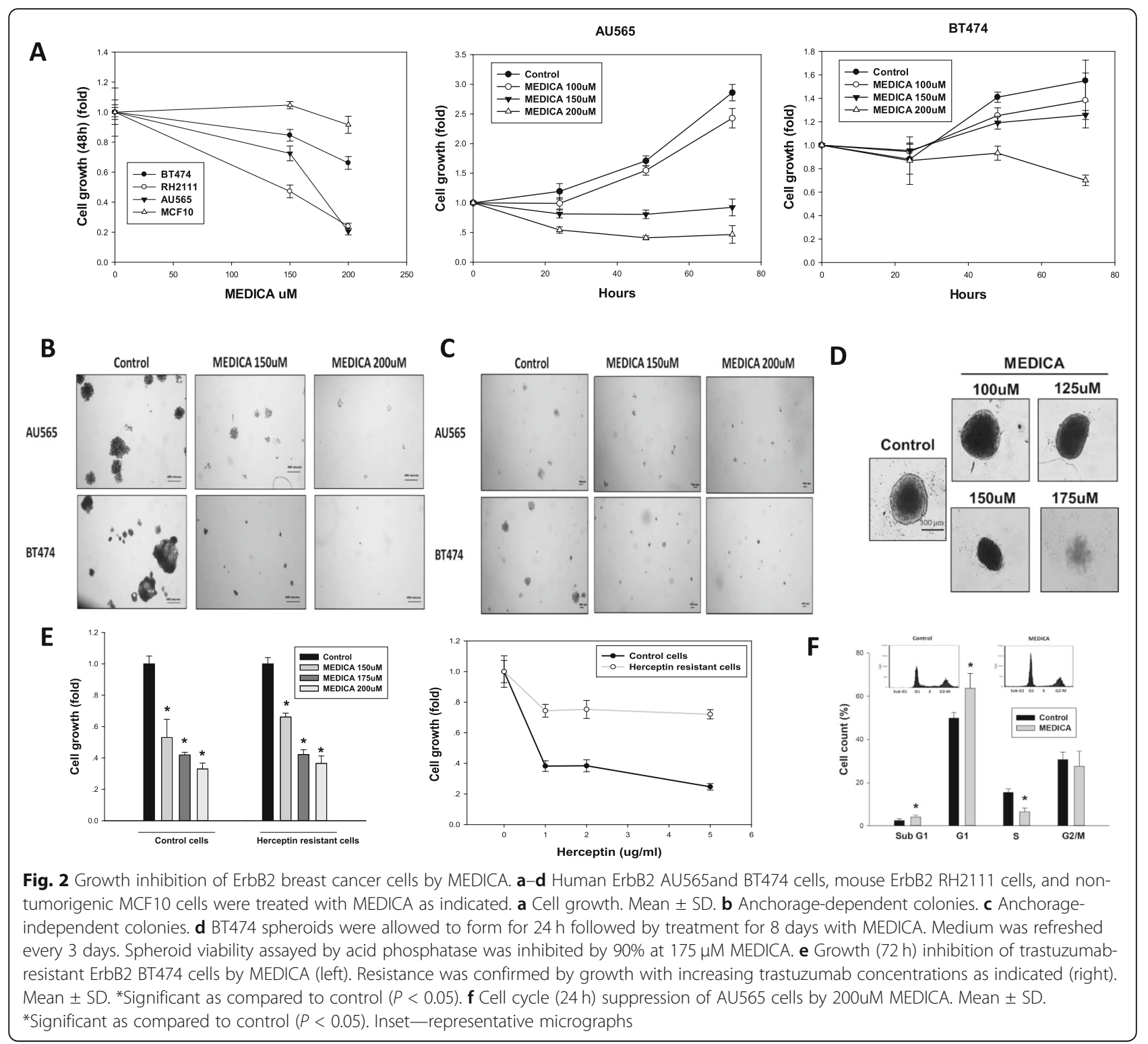

Hence, the effects of MEDICA in driving ErbB loss, in inhibiting mTORC1 activity, and in suppressing ErbB survival may be primarily ascribed to its mitochondrial activity. Of note, in line with MEDICA inhibition of mitochondrial complexes I and III (Fig. 5b), as contrasted with biguanides [37], infective NDI1 was fully effective in rescuing growth inhibition by phenformin, but only partly effective in rescuing growth inhibition by MEDICA (Fig. 6e).

Cell growth suppression by mitochondrial complex I inhibitors in some cancer cell lines has recently been ascribed to aspartate limitation, being rescued by added pyruvate, aspartate or by infecting aspartate transporters [39-42]. Hence, growth inhibition by MEDICA could in principle be accounted for by aspartate limitation. However, growth inhibition of AU565 or BT474 cells by
MEDICA, rotenone, or phenformin was not rescued by added pyruvate or aspartate (Suppl Fig 1), implying that inhibition of AU565 or BT474 cell growth by mitochondrial complex I inhibitors is not governed by aspartate limitation. Moreover, whereas growth inhibition of A549 cells by metformin was rescued by added pyruvate or aspartate, in line with previous reports [42], inhibition of A549 cell growth by MEDICA persisted in the presence of added pyruvate or aspartate (Suppl Fig 2). Hence, growth inhibition by MEDICA surpasses aspartate limitation.

Inhibition of mTORC1 activity due to mitochondrial stress prompted our interest in dissecting elements of the mTORC1 system that transduce inhibition of mTORC1 activity by MEDICA. mTORC1 activity may be inhibited by limiting ATP, by activating TSC1,2 and/ or Raptor by AMPK, by stabilizing TSC1,2 by REDD 1 , 


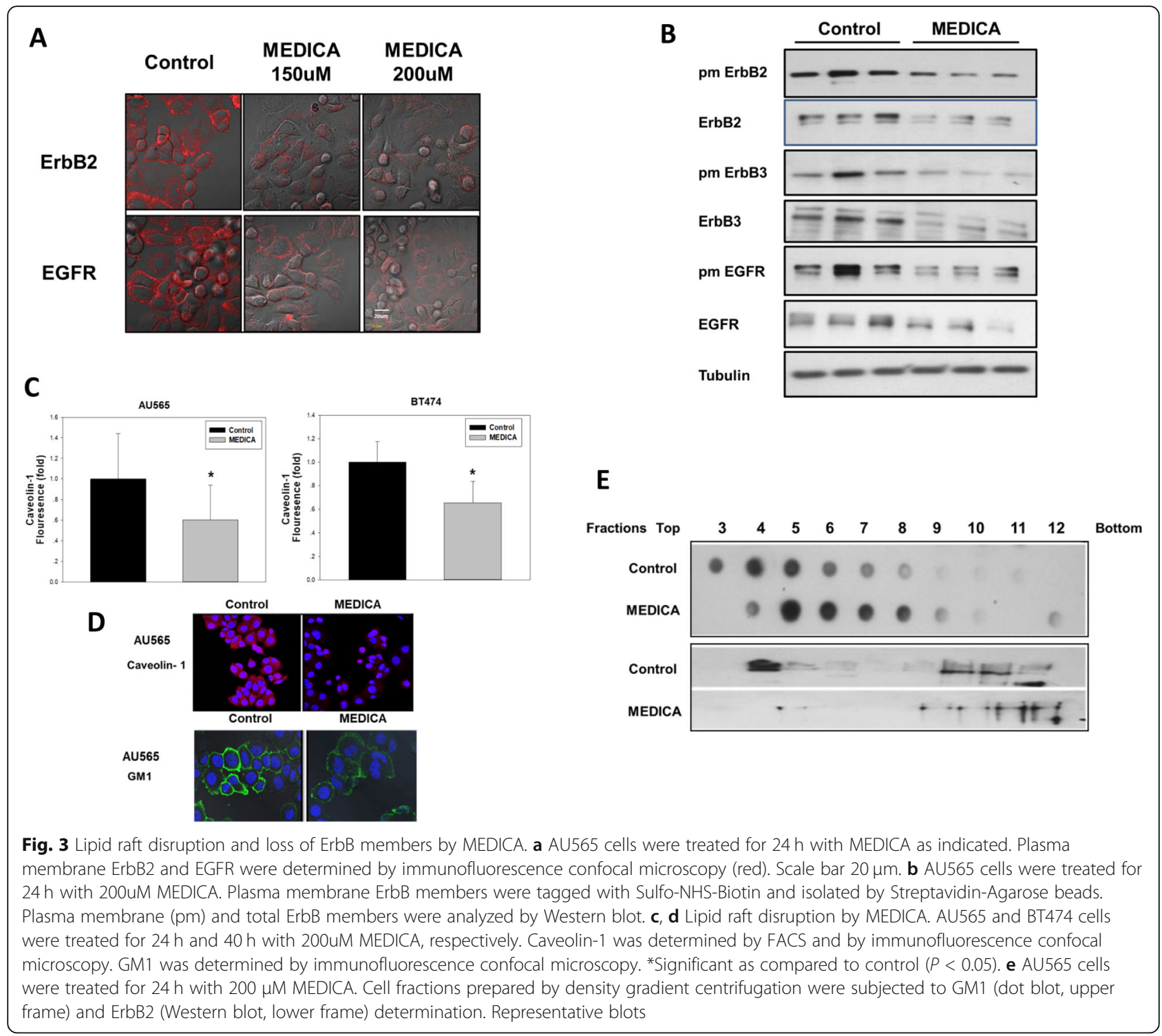

and/or by modulating the activity of RAGs by Sestrin 2 or lysosomal v-ATPase [43]. Indeed, MEDICA treatment resulted in induced-REDD1, phospho-AMPK(Thr172), and its ACC(Ser79) substrate, being rescued by infected NDI1 (Fig. 7a). MEDICA treatment further resulted in induced Sestrin2 (Fig. 7a). However, inhibition of mTORC1 activity by MEDICA, as verified by mTORC1 downstream phospho-S6K1(Thr389), phospho-S6(Ser240/244), and phospho-4EBP(Thr37/46) substrates, was not rescued by downregulating Sestrin2 or AMPK by respective shRNAs (Fig. 7b, c), or by constitutive RagB. Inhibition of mTORC1 activity by MEDICA was partially rescued by infected shREDD1 (Fig. 7d), indicating that TSC1,2 stabilization by MEDICA-induced REDD1 may partly account for mTORC1 inhibition by MEDICA. Of note, ErbB2 loss by MEDICA still prevails upon partially rescuing mTORC1 activity by infected shREDD1 (Fig. 7e), implying that suppression of ErbB members and inhibition of mTORC1 activity by MEDICA are independently driven by mitochondrial targeting.

\section{Discussion}

MEDICA treatment is shown here to suppress ErbB2 breast tumors and lung metastasis in transgenic mice that express the activated ErbB2/neu oncogene under the control of the mouse MMTV long terminal repeat (LTR) promoter. Suppression of ErbB2 breast cancer by MEDICA was corroborated by suppressing ErbB2/neu xenografts in NOD/SCID mice. MEDICA effects were further verified by growth suppression of trastuzumabsensitive and trastuzumab-resistant AU565 and BT474 human ErbB2 breast cancer cells. MEDICA inhibited the viability of ErbB2 tumor cells, colonies, and spheroids, while no resistance to MEDICA was observed in ErbB2 


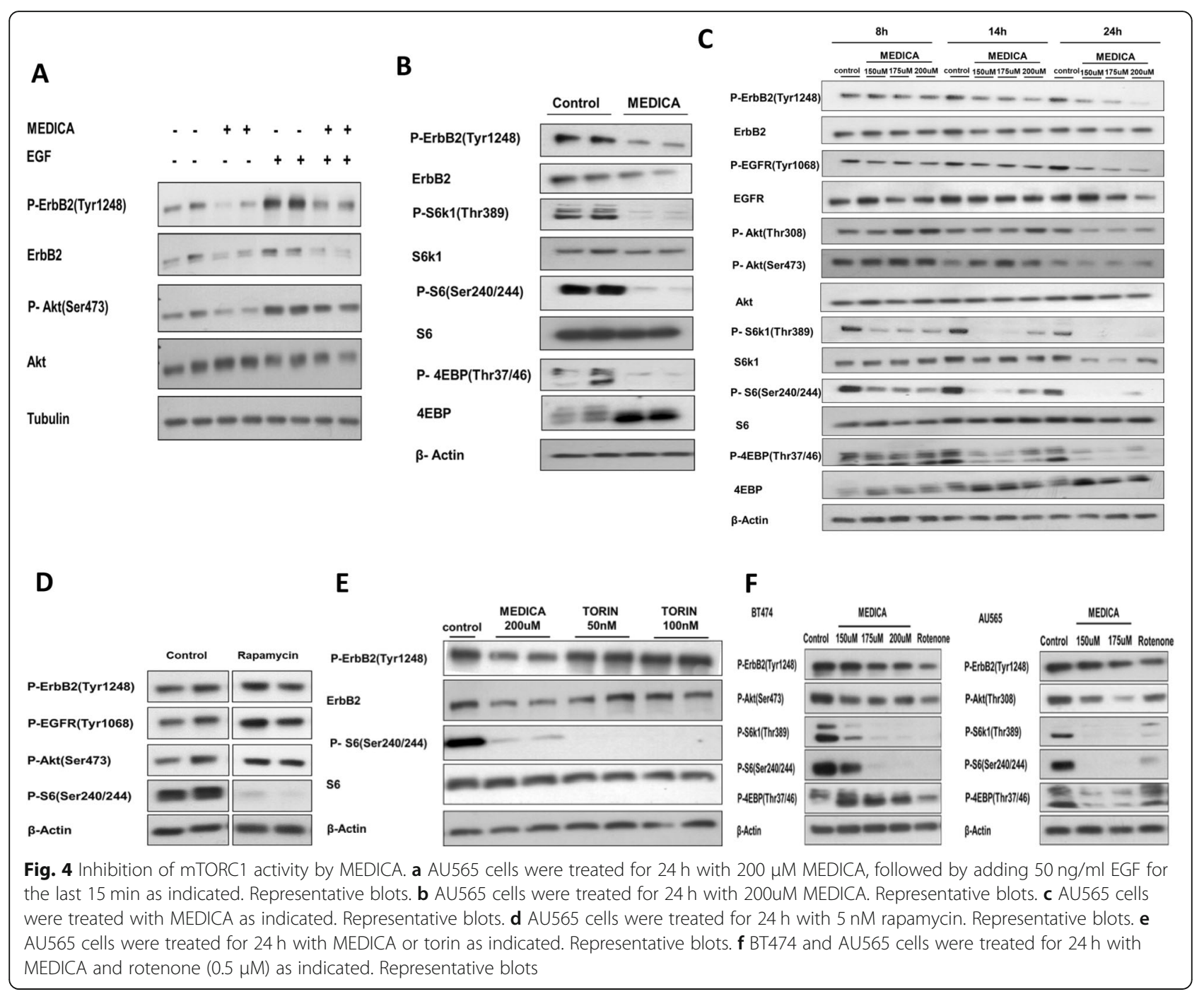

cells subjected to prolonged continuous culturing with MEDICA.

Suppression of ErbB2 breast tumors by MEDICA in ErbB2/neu mouse transgenes as well as in human ErbB2 breast cancer cells was accompanied by loss of plasma membrane ErbB2, together with other ErbB family members, including EGFR (ErbB1) and ErbB3. Since ErbB2 breast cancer is driven by homodimerization and/or heterodimerization of the amplified ErbB2 with other ErbB receptors, the loss of ErbB family receptors may further promote MEDICA efficacy in suppressing ErbB2 breast cancer. Loss of plasma membrane ErbB family members by MEDICA was not due to decrease in respective ErbB transcripts, but to lipid raft disruption by MEDICA, as verified by the concomitant loss of lipid raft caveolin-1 and GM1. Since stabilized lipid rafts form platforms for receptor tyrosine kinases docking and their signaling cascades [31, 32], lipid raft disruption and loss of ErbB family members by MEDICA resulted in abrogating signaling cascades downstream of ErbB receptors, including PI3K/Akt and mTORC1 as verified by its downstream targets S6K1(Thr389), S6(Ser240/244), and 4EBP(Thr37/46). Suppression of mTORC1 activity by MEDICA could apparently be ascribed to abrogation of ErbB signaling pathways leading to mTORC1. However, mTORC1 activity was inhibited by MEDICA prior to loss of ErbB receptors, while canonical mTORC1 inhibitors (rapamycin, torin) failed to disrupt ErbB members, implying that MEDICA may act as novel mTORC1 kinase inhibitor independently of abrogating the ErbB receptors and their signaling cascades (Fig. 7f).

The double hit of MEDICA in inhibiting mTORC1 activity while concomitantly abrogating ErbB signaling is noteworthy in terms of resistance to current treatment strategies. Indeed, $20 \%$ of ErbB2 breast cancer patients present primary resistance to ErbB2-targeting agents (e.g., trastuzumab, prastuzumab, lapatinib), and $70 \%$ of patients with ErbB2 metastatic cancer present acquired 


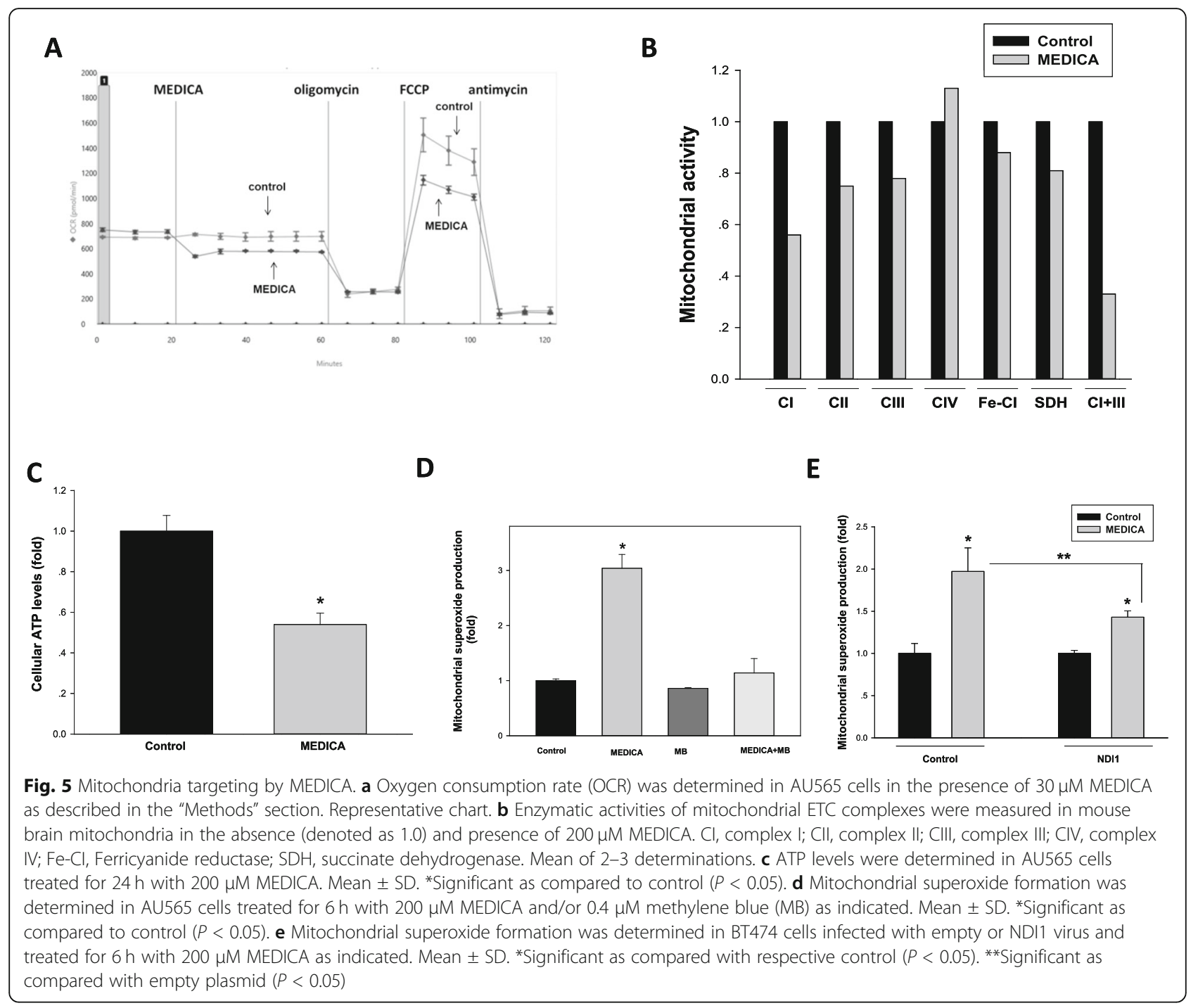

resistance [2]. Resistance may result from epitope masking, truncation or mutation of the ErbB2 receptor, overexpression of other ErbB family members or alternative survival receptor tyrosine kinases (RTK) (e.g., IR, IGF1R, PDGFR), and/or mutated downstream survival transduction pathways (e.g., PTEN/PI3K/Akt, MEK/MAPK). All converge onto mTORC1 and/or mTORC2, prompting treatment strategies that target mTOR. However, inhibition of mTORC1 by rapalogs may result in Akt(Thr308, Ser473) and/or MEK/MAPK phosphorylation and resistance, due to de-suppression of ErbB members and/or alternative survival RTKs and/or mTORC2 that are restrained by active mTORC1, but become activated upon mTORC1 inhibition [44-48]. Replacing rapalogs by mTOR kinase inhibitors (e.g., Torin) that inhibit both mTORC1 and mTORC2, may overcome Akt(Ser473) phosphorylation, but still result in resistance due to active phospho-Akt(Thr308) [44]. Hence, the inherent feedback that controls the ErbB2/mTOR network requires concomitant suppression of ErbB members and/ or PI3K/Akt when targeting mTORC1 [48]. However, these drug combination protocols are complicated by multi-drug toxicity [49]. In contrast to mTOR canonical inhibitors, treatment of ErbB2 breast cancer by MEDICA allows for both, inhibition of mTORC1 activity while concomitantly disrupting ErbB family members and their signaling cascades (Figs. 4a-c and 6a). Hence, MEDICA may offer a novel mode of suppressing mTORC1 activity.

The bifunctional activity of MEDICA in the ErbB/ mTORC1 context is partly driven by targeting mitochondria complex I. Indeed, by-passing mitochondrial complex I by infected yeast NADH dehydrogenase (NDI1) resulted in partly rescuing ErbB expression, mTORC1 activity, and cell growth. In line with that, rescue of MTORC1, ErbB2, and its signaling pathways by NDI1 infection was more evident in cells cultured in galactose medium instead of glucose, namely, under conditions that drive cells to maximize mitochondrial oxidative phosphorylation rather 


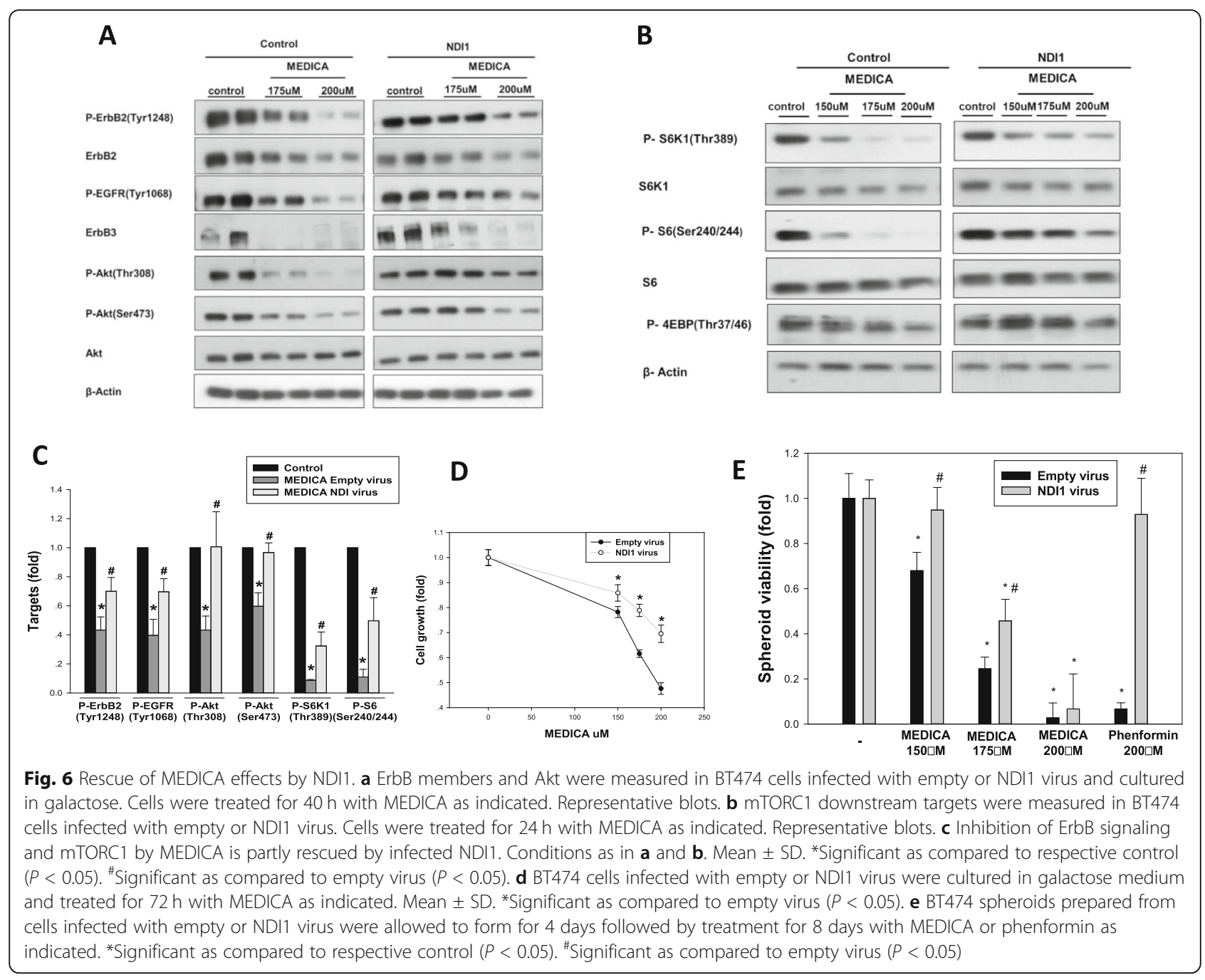

than relying on glycolytic ATP production $[38,50]$. The mitochondrial metabolic stress induced by MEDICA may result in suppressing mTORC1 activity by promoting lysosomal/TSC1,2 association [35]. Indeed, suppression of mTORC1 activity by MEDICA was rescued by abrogating REDD1, implying that TSC1,2 stability is required for MEDICA activity in suppressing mTORC1. Lipid raft disruption with loss of caveolin-1 and ErbB receptors has recently been reported to be mediated by NDRG1 overexpression $[51,52]$, that could in principle be induced by mitochondrial metabolic stress [53]. However, no increase in NDRG1 expression was evident in ErbB2 breast cancer cells cultured in the presence of MEDICA. The punctuated GM1 appearance of MEDICA-treated cells may indicate clustering of lipid rafts due to oxidative stress [33].

Retrospective clinical studies have indicated improved disease-free and overall survival of diabetic ErbB2 luminal B breast cancer patients treated with metformin [10-13]. The efficacy of add-on metformin in the treatment of ErbB2 breast cancer in non-diabetic patients still remains to be prospectively verified. Of note, add-on metformin to neo-adjuvant treatment of ErbB2 breast cancer in non-diabetic patients has recently been reported to fail in improving pathologic complete response [54], indicating perhaps metformin limitation in the non-diabetic breast cancer context. In light of the role of hyperinsulinemia in breast cancer growth and migration [55], the robust insulin-sensitizing anti-diabetic activity of MEDICA [17, 18, 20, 21] may translate to improved treatment of ErbB2 breast cancer in both diabetic and non-diabetic patients.

\section{Conclusions}

In spite of the advances accomplished in treating ErbB2 breast cancer, the ErbB2 cancer challenge still remains an unmet need. Also, mTORC1 is activated in up to $80 \%$ of human cancers [56], while current mTOR inhibitors are of limited clinical efficacy due to resistance invoked by de-suppression of mTOR feedback networks and due to worrisome 


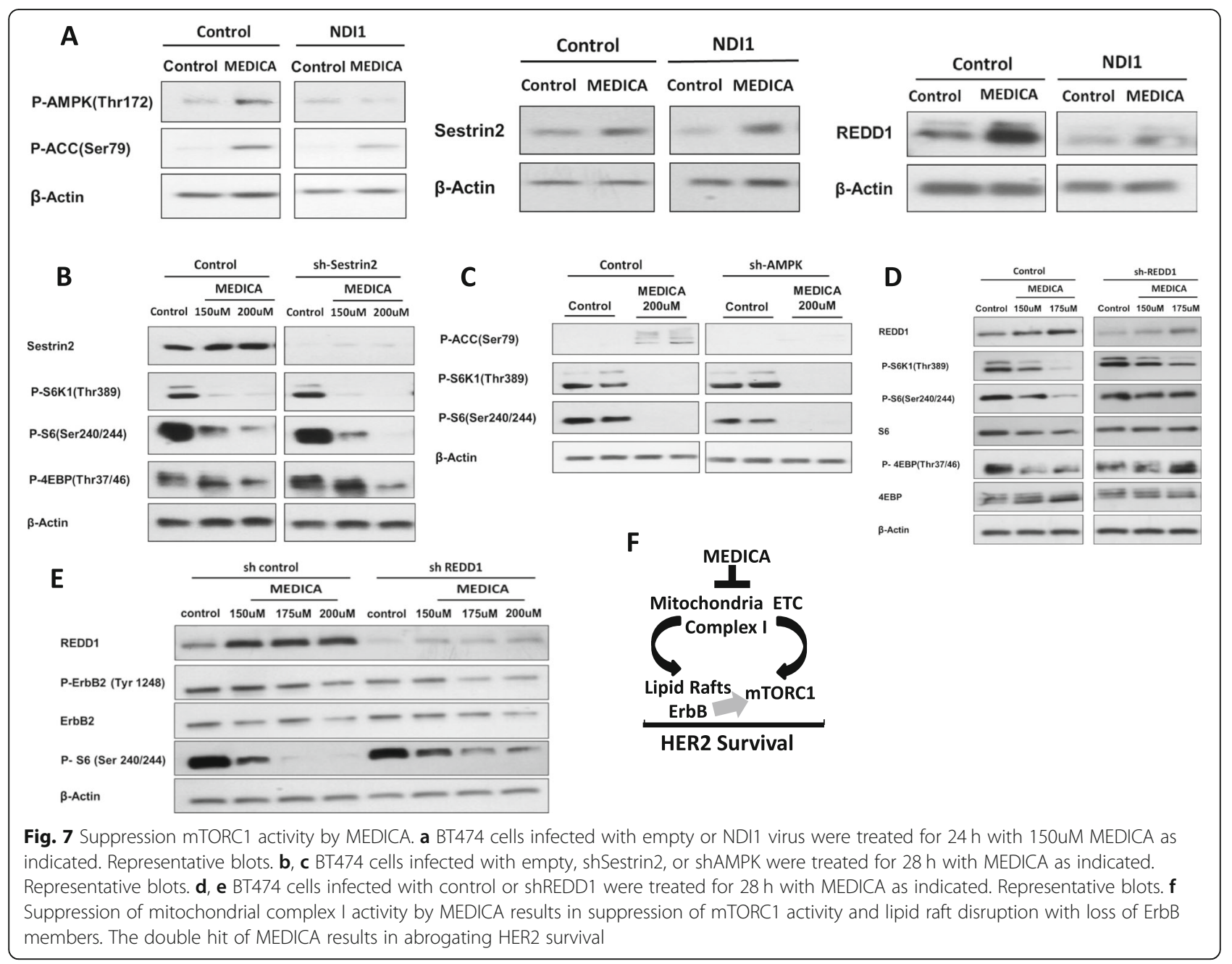

side effects. If proved in future clinical studies, the bifunctional activity of MEDICA in abrogating ErbB receptors and inhibiting mTORC1 activity (Fig. 7f) may offer a novel treatment mode for mTORC1driven cancers in general and ErbB2 breast cancer in particular.

\section{Supplementary information}

Supplementary information accompanies this paper at https://doi.org/10. 1186/s40170-020-00223-8.

Additional file 1:. Supplemental figures

\section{Abbreviations}

AMPK: AMP-activated protein kinase; FCS: Fetal calf serum; LCFA: long-chain fatty acids; MMTV: Mouse mammary tumor virus; NDI1: Yeast NADH dehydrogenase; PyMT: Polyoma middle T antigen; RTK: Receptor tyrosine kinases; T2D: Type 2 diabetes

Acknowledgements

Not applicable.
Authors' contributions

Conception and design: SE, RH, and JBT. Data acquisition: SE, RH, GV, and AS. Data analysis: SE, RH, and JBT. Manuscript: SE, RH, GV, AS, and JBT. The authors read and approved the final manuscript.

Funding

Supported by internal grant of the Hebrew University.

Availability of data and materials

All data generated or analyzed during this study are included in this published article.

\section{Ethics approval and consent to participate}

Animal care and experimental procedures were in accordance with the accredited animal ethics committee of the Hebrew University Medical School.

\section{Consent for publication}

Not applicable.

\section{Competing interests}

JBT is a director in SyndromeX. SyndromeX develops drugs for the Metabolic Syndrome.

\section{Author details}

${ }^{1}$ Dept of Human Nutrition and Metabolism, Hebrew University Medical School, 91120 Jerusalem, Israel. ${ }^{2}$ Dept of Pathology, Hadassah-Hebrew 
University Medical Center, 91120 Jerusalem, Israel. ${ }^{3}$ Department of Genetics and Metabolic Diseases, Hadassah-Hebrew University Medical Center, 91120 Jerusalem, Israel.

Received: 4 June 2019 Accepted: 1 July 2020

Published online: 14 July 2020

\section{References}

1. Breast cancer: facts and figures 2017-2018. https://www.cancer.org/content/ $\mathrm{dam} /$ cancer-org/research/cancer-facts-and-statistics/breast-cancer-facts-andfigures/breast-cancer-facts-and-figures-2017-2018.pdf.

2. Sagun Parakh, Hui K. Gan, Adam C. Parslow, Ingrid J.G. Burvenich, Antony W. Burgess, Andrew M. Scott. Evolution of anti-HER2 therapies for cancer treatment. Cancer Treat Rev. 2017;59:1-21.

3. Zanardi E, Bregni G, de Braud F. Di Cosimo S. Semin. Better together: targeted combination therapies in breast cancer. Oncol. 2015;42:887-95.

4. Ford ES, Li C, Zhao G. Prevalence and correlates of metabolic syndrome based on a harmonious definition among adults in the US. J Diabetes. 2010; 2:180-93.

5. Boyle $\mathrm{P}$, Boniol $\mathrm{M}$, Koechlin $\mathrm{A}$, et al. Diabetes and breast cancer risk: a metaanalysis. Br J Cancer. 2012;107:1608-17.

6. Ferguson RD, Gallagher EJ, Cohen D, Tobin-Hess A, Alikhani N, Novosyadly R, Haddad N, Yakar S, LeRoith D. Hyperinsulinemia promotes metastasis to the lung in a mouse model of Her2-mediated breast cancer. Endocr Relat Cancer. 2013;20:391-401.

7. Park J, Morley TS, Kim M, Clegg DJ, Scherer PE. Obesity and cancermechanisms underlying tumor progression and recurrence. Nat Rev Endocrinol. 2014;10:455-65.

8. Bowker SL, Majumdar SR, Veugelers P, Johnson JA. Increased cancer-related mortality for patients with type 2 diabetes who use sulfonylureas or insulin. Diabetes Care. 2006;29:254-8.

9. Thakkar B, Aronis KN, Vamvini MT, Shields K, Mantzoros CS. Metformin and sulfonylureas in relation to cancer risk in type II diabetes patients: a metaanalysis using primary data of published studies. Metabolism. 2013;62:92234.

10. Sonnenblick A, Agbor-Tarh D, Bradbury I, Di Cosimo S, Azim HA Jr, Fumagalli D, Sarp S, Wolff AC, Andersson M, Kroep J, Cufer T, Simon SD, Salman P, Toi M, Harris L, Gralow J, Keane M, Moreno-Aspitia A, PiccartGebhart M, de Azambuja E. Impact of diabetes, insulin, and metformin use on the outcome of patients with human epidermal growth factor receptor 2-positive primary breast cancer: analysis from the ALTTO phase III randomized trial. J Cin Oncol. 2017:35:1421-9.

11. Kim HJ, Kwon H, Lee JW, Kim HJ, Lee SB, Park HS, Sohn G, Lee Y, Koh BS, Yu $\mathrm{JH}$, Son BH, Ahn SH. Metformin increases survival in hormone receptorpositive, HER2-positive breast cancer patients with diabetes. Breast Cancer Res. 2015;17:64.

12. He X, Esteva FJ, Ensor J, Hortobagyi GN, Lee MH, Yeung SC. Metformin and thiazolidinediones are associated with improved breast cancer-specific survival of diabetic women with HER2+ breast cancer. Ann Oncol. 2012;23: 1771-80.

13. Jiralerspong S, Palla SL, Giordano SH, Meric-Bernstam F, Liedtke C, Barnett CM, Hsu L, Hung MC, Hortobagyi GN, Gonzalez-Angulo AM. Metformin and pathologic complete responses to neoadjuvant chemotherapy in diabetic patients with breast cancer. J Clin Oncol. 2009;27:3297-302.

14. Guo Z, Zhao M, Howard EW, Zhao Q, Parris AB, Ma Z, Yang X. Phenformin inhibits growth and epithelial-mesenchymal transition of ErbB2overexpressing breast cancer cells through targeting the IGF1R pathway. Oncotarget. 2017:8:60342-57.

15. Parris $A B$, Zhao Q, Howard EW, Zhao M, Ma Z, Yang X. Buformin inhibits the stemness of erbB-2-overexpressing breast cancer cells and premalignant mammary tissues of MMTV-erbB-2 transgenic mice. J Exp Clin Cancer Res. 2017;36:28.

16. Alimova IN, Liu B, Fan Z, Edgerton SM, Dillon T, Lind SE, Thor AD. Metformin inhibits breast cancer cell growth, colony formation and induces cell cycle arrest in vitro. Cell Cycle. 2009;8:909-15.

17. Za'tara G, Bar-Tana J, Kalderon B, Suter M, Morad E, Samovski D, Neumann D, Hertz R. AMPK activation by long chain fatty acyl analogs. Biochem Pharmacol. 2008:76:1263-75.

18. Zatara G, Hertz R, Shaked M, Mayorek N, Morad E, Grad E, Cahan A, Danenberg HD, Unterman TG, Bar-Tana J. Suppression of FoxO1 activity by long-chain fatty acyl analogs. Diabetes. 201;60:1872-81.
19. Kalderon B, Azazmeh N, Azulay N, Vissler N, Valitsky M, Bar-Tana J. Suppression of adipose lipolysis by long-chain fatty acid analogs. Journal of Lipid Research. 2012;53:868-78.

20. Valitsky M, Hoffman A, Unterman T, Bar-Tana J. Insulin sensitizer prevents and ameliorates experimental type 1 diabetes. Am J Physiol Endocrinol Metab. 2017:313:E672-80.

21. Algamas-Dimantov A, Yehuda-Shnaidman E, Hertz R, Peri I, Bar-Tana J, Schwartz B. Prevention of diabetes-promoted colorectal cancer by (n-3) polyunsaturated fatty acids and (n-3) PUFA mimetic. Oncotarget. 2014;5 9851-63.

22. Gluschnaider U, Hertz R, Ohayon S, Smeir E, Smets M, Pikarsky E, Bar-Tana J. Long-chain fatty acid analogues suppress breast tumorigenesis and progression. Cancer Res. 2014;74:6991-7002.

23. Longati P, Jia X, Eimer J, Wagman A, Witt MR, Rehnmark S, Verbeke C, Toftgård R, Löhr M, Heuchel RL. 3D pancreatic carcinoma spheroids induce a matrix-rich, chemoresistant phenotype offering a better model for drug testing. BMC Cancer. 2013;13:95.

24. Atiq R, Hertz R, Eldad S, Smeir E, Bar-Tana J. Suppression of B-Raf(V600E) cancers by MAPK hyper-activation. Oncotarget. 2016;7:18694-704.

25. Saada A, Bar-Meir M, Belaiche C, Miller C, Elpeleg O. Evaluation of enzymatic assays and compounds affecting ATP production in mitochondrial respiratory chain complex I deficiency. Anal Biochem. 2004;335:66-72.

26. Bar-Tana J, Ben-Shoshan S, Blum J, Migron Y, Hertz R, Pill J, Rose-Khan G, Witte EC. Synthesis and hypolipidemic and antidiabetogenic activities of beta,beta,beta','beta'-tetrasubstituted, long-chain dioic acids. J Med Chem. 1989:32:2072-2084.

27. Muller WJ, Sinn E, Pattengale PK, Wallace R, Leder P. Single-step induction of mammary adenocarcinoma in transgenic mice bearing the activated $c$ neu oncogene. Cell. 1988:54:105-15.

28. Guy CT, Webster MA, Schaller M, Parsons TJ, Cardiff RD, Muller WJ. Expression of the Neu protooncogene in the mammary epithelium of transgenic mice induces metastatic disease. Proc Natl Acad Sci USA. 1992;89: 10578-82.

29. Subik K, Lee JF, Baxter L, Strzepek T, Costello D, Crowley P, Xing L, Hung MC, Bonfiglio T, Hicks DG, Tang P. The expression patterns of ER, PR, HER2, CK5/6, EGFR, Ki-67 and AR by immunohistochemical analysis in breast cancer cell lines. Breast Cancer (Auckl). 2010;4:35-41.

30. Lee $\mathrm{CH}$, Yu CC, Wang BY, Chang WW. Tumorsphere as an effective in vitro platform for screening anti-cancer stem cell drugs. Oncotarget. 2016;7:1215-26.

31. Nagy P, Vereb G, Sebestyén Z, Horváth G, Lockett SJ, Damjanovich S, Park $J W$, Jovin TM, Szöllosi J. Lipid rafts and the local density of ErbB proteins influence the biological role of homo- and heteroassociations of ErbB2. J Cell Sci. 2002;115:4251-62.

32. Babina IS, Donatello $S$, Nabi IR, Hopkins AM. Lipid rafts as master regulators of breast cancer cell function. In: Breast cancer - carcinogenesis, cell growth and signalling pathways. Editors: M. Gunduz, E. Gunduz. InTech, ISBN 978953-307-714-7. 2011:401-428.

33. Nourissat $P$, Travert $M$, Chevanne $M$, Tekpli X, Rebillard A, Le Moigne-Müller G, Rissel M, Cillard J, Dimanche-Boitrel MT, Lagadic-Gossmann D, Sergent O. Ethanol induces oxidative stress in primary rat hepatocytes through the early involvement of lipid raft clustering. Hepatology. 2008:47:59-70.

34. Santos AL, Preta G. Lipids in the cell: organisation regulates function. Cell Mol Life Sci. 2018:75:1909-27.

35. Demetriades C, Plescher M, Teleman AA. Lysosomal recruitment of TSC2 is a universal response to cellular stress. Nat Commun. 2016;7:10662.

36. Atamna H, Nguyen A, Schultz C, Boyle K, Newberry J, Kato H, Ames BN. Methylene blue delays cellular senescence and enhances key mitochondrial biochemical pathways. FASEB Journal. 2008;22:703-12.

37. Wheaton WW, Weinberg SE, Hamanaka RB, Soberanes S, Sullivan LB, Anso E, Glasauer A, Dufour E, Mutlu GM, Budigner GS, Chandel NS. Metformin inhibits mitochondrial complex I of cancer cells to reduce tumorigenesis. Elife. 2014:3:e02242..

38. Aguer C, Gambarotta D, Mailloux RJ, Moffat C, Dent R, McPherson R, Harper ME. Galactose enhances oxidative metabolism and reveals mitochondrial dysfunction in human primary muscle cells. PLoS One. 2011;6:e28536.

39. Birsoy K, Wang T, Chen WW, Freinkman E, Abu-Remaileh M, Sabatini DM. An essential role of the mitochondrial electron transport chain in cell proliferation is to enable aspartate synthesis. Cell. 2015;162:540-51.

40. Sullivan LB, Gui DY, Hosios AM, Bush LN. Freinkman E, Vander HeidenMG. Supporting aspartate biosynthesis is an essential function of respiration in proliferating cells. Cell. 2015;162:552-63. 
41. Sullivan LB, Luengo A, Danai LV, Bush LN, Diehl FF, Hosios AM, Lau AN, Elmiligy S, Malstrom S, Lewis CA, Vander Heiden MG. Aspartate is an endogenous metabolic limitation for tumour growth. Nat Cell Biol. 2018;20: 782-8.

42. Garcia-Bermudez J, Baudrier L, La K, Zhu XG, Fidelin J, Sviderskiy VO, Papagiannakopoulos T, Molina H, Snuderl M, Lewis CA, Possemato RL, Birsoy K. Aspartate is a limiting metabolite for cancer cell proliferation under hypoxia and in tumours. Nat Cell Biol. 2018;20:775-81.

43. Saxton RA, Sabatini DM. mTOR signaling in growth, metabolism, and disease. Cell. 2017;168:960-76.

44. Rodrik-Outmezguine VS, Chandarlapaty S, Pagano NC, Poulikakos PI, Scaltriti M, Moskatel E, Baselga J, Guichard S, Rosen N. mTOR kinase inhibition causes feedback-dependent biphasic regulation of AKT signaling. Cancer Discov. 2011;1:248-59.

45. Chandarlapaty S, Sawai A, Scaltriti M, Rodrik-Outmezguine V, Grbovic-Huezo O, Serra V, Majumder PK, Baselga J, Rosen N. AKT inhibition relieves feedback suppression of receptor tyrosine kinase expression and activity. Cancer Cell. 2011;19:58-71.

46. O'Reilly KE, Rojo F, She QB, Solit D, Mills GB, Smith D, Lane H, Hofmann F, Hicklin DJ, Ludwig DL, Baselga J, Rosen N. mTOR inhibition induces upstream receptor tyrosine kinase signaling and activates Akt. Cancer Res. 2006:66:1500-8.

47. Carracedo A, Ma L, Teruya-Feldstein J, Rojo F, Salmena L, Alimonti A, Egia A, Sasaki AT, Thomas G, Kozma SC, Papa A, Nardella C, Cantley LC, Baselga J, Pandolfi PP. Inhibition of mTORC1 leads to MAPK pathway activation through a PI3K-dependent feedback loop in human cancer. J Clin Invest. 2008;118:3065-74

48. Chandarlapaty S. Negative feedback and adaptive resistance to the targeted therapy of cancer. Cancer Discov. 2012;2:311-9.

49. Bayat Mokhtari R, Homayouni TS, Baluch N, Morgatskaya E, Kumar S, Das B, Yeger H. Combination therapy in combating cancer. Oncotarget. 2017;8: 38022-43.

50. Kase ET, Nikolić N, Bakke SS, Bogen KK, Aas V, Thoresen GH, Rustan AC Remodeling of oxidative energy metabolism by galactose improves glucose handling and metabolic switching in human skeletal muscle cells. PLoS One. 2013;8:e59972

51. Menezes SV, Sahni S, Kovacevic Z, Richardson DR. J. Interplay of the ironregulated metastasis suppressor NDRG1 with epidermal growth factor receptor (EGFR) and oncogenic signaling. Biol Chem. 2017;292:12772-82.

52. Mi L, Zhu F, Yang X, Lu J, Zheng Y, Zhao Q, Wen X, Lu A, Wang M, Zheng $M$, Ji J, Sun J. The metastatic suppressor NDRG1 inhibits EMT, migration and invasion through interaction and promotion of caveolin-1 ubiquitylation in human colorectal cancer cells. Oncogene. 2017;36:4323-35.

53. Fang BA, Kovačević Ž, Park KC, Kalinowski DS, Jansson PJ, Lane DJ, Sahni S, Richardson DR. Molecular functions of the iron-regulated metastasis suppressor, NDRG1, and its potential as a molecular target for cancer therapy. Biochim Biophys Acta. 1845;2014:1-19.

54. Pernas S, Dorca J, Álvarez-López I, et al. Safety and efficacy of neoadjuvant metformin with trastuzumab and chemotherapy in women with HER2positive early breast cancer: a randomized, open-label, multicenter, phase 2 trial. San Antonio Breast Cancer Symposium (SABCS).2017.

55. Kang C, LeRoith D, Gallagher EJ. Diabetes, obesity, and breast cancer. Endocrinology. 2018;159:3801-12.

56. Howell JJ, Ricoult SJ, Ben-Sahra I, Manning BD. A growing role for mTOR in promoting anabolic metabolism. Biochem Soc Trans. 2013:41:906-12.

\section{Publisher's Note}

Springer Nature remains neutral with regard to jurisdictional claims in published maps and institutional affiliations.

Ready to submit your research? Choose BMC and benefit from:
- fast, convenient online submission
- thorough peer review by experienced researchers in your field
- rapid publication on acceptance
- support for research data, including large and complex data types
- gold Open Access which fosters wider collaboration and increased citations
- maximum visibility for your research: over 100M website views per year
At BMC, research is always in progress.
Learn more biomedcentral.com/submissions

